\title{
Maxent modeling for predicting the potential distribution of Arbutus andrachne L. belonging to climate change in Turkey.
}

\author{
Ayse Gul Sarikaya ${ }^{1, *}$, Omer K. Orucu ${ }^{2}$ \\ ${ }^{1}$ Dept. of Forest Engineering, Bursa Technical University, Faculty of Forestry, Bursa,Turkey. \\ ${ }^{2}$ Dept. of Landscape Architecture, Suleyman Demirel University, Architecture Faculty, \\ Isparta,Turkey. \\ *Corresponding author: aysegul.sarikaya@btu.edu.tr
}

\begin{abstract}
Arbutus andrachne L., the strawberry tree, is an evergreen shrub or small tree in the Turkish flora and has broad uses. The wood is used for decorative purposes, packaging, and manufacturing furniture. The fruits are edible and used in treating many kinds of diseases. However, global warming might affect the abundance of this symbolic plant's distribution, especially at higher latitudes. This study was conducted to determine the expected effects of climate change on $A$. andrachne. For this purpose, Representative Concentration Pathway (RCP) 4.5 and RCP 8.5 were used to expect climate change scenarios for 2050 and 2070, and potential distribution areas of $A$. andrachne were presented. The results indicated that the distribution of $A$. andrachne would decrease in the southern regions of Turkey. However, the spread of the species could be expanded in the western and northern areas. It is also expected that there would be potential habitat losses, which would affect the distribution of $A$. andrachne.
\end{abstract}

Keywords: Arbutus andrachne; distribution; Maxent; RCP 4.5; RCP 8.5; Turkey.

\section{Introduction}

All living organisms in nature (animals, plants, and microorganisms) are living in a delicate balance. Animals and plants are used to meet human needs (Gezgin, 2006). The demand for forest resources, considered one of the most important natural resources, has changed qualitatively and quantitatively due to rapid population growth during the second half of the twentieth century. Other factors such as technological developments, increased income, and individuals' education levels are other factors that led to the over-exploitation of natural resources (Ozkan \& Akbulut, 2014). In recent years, the demand for non-wood forest products has increased significantly; therefore, forest resources have drawn new awareness (Bektas, 2014). Today, with the evaluation of plants in each country's flora, it is becoming increasingly important to cultivate new fruit species, expand their production and use areas, and use new plant species in landscape studies (Onursal \& Gozlekci 2007; Nuh, 2015).

There are 12 species in the genus Arbutus, which belong to the Ericaeae family and are found in the Mediterranean, North West, and Central America. Arbutus taxa are evergreen, woody plants that take the form of tall shrubs. Arbutus unedo and $A$. andrachne are growing naturally in Turkey (Ansin \& Ozkan, 1993). These two species are of great importance in Turkish forestry. This importance comes from the fact that these species' wood is used in 
packaging, chair and furniture construction, decorative, and biofuel. Also, the fruits are commonly consumed by humans and animals because they are rich in sugar and vitamin C (Sumbul et al., 2005; Aslan, 2011).

Arbutus andrachne has a wide distribution of up to $800 \mathrm{~m}$ elevations in southern Albania, Greece, Turkey, the Black Sea to Crimea to Lebanon and northern Iraq (Kayacik, 1982). It spreads in maquis stands, pine forests in the arid cliffs of coastal regions in Turkey. $A$. andrachne is a slow-growing species that develops well in nitrogenous, well-drained, and fertile soils but can also grow on stony, rocky slopes, calcareous and volcanic rock (Gungor et al., 2002).

Arbutus andrachne is an evergreen, thickly branched shrub or small tree that can reach up to 5-6 $\mathrm{m}$ in height. Young shoots are feathered. The leaves are broad, oval with a straight edge. The leaves are geared only in young plants. Their upper faces are dark, but the lower sides are light green and lint-free. The greenish-creamcolored flowers form in perforated compound clusters and bloom from March to April. The fruits, which ripen in autumn, are $1.0-1.5 \mathrm{~cm}$ in diameter and orangeyellow to light red (Kayacik, 1982).

Arbutus, one of the symbolic plants of Mediterranean vegetation with its attractive color, large leaves, and striking fruits in autumn, is also used as handicraft material due to the hardness of its wood texture. Its fruits contain plenty of tannins. Young shoots and leaves are used in the manufacture of different types of medicines. As the other parts of the plant contain high tannin levels, they are used in herbal medicine to relieve stomach and bowel laziness, reduce high blood pressure, relieve liver bloating, and have antipyretic properties. The plant is also useful in the spill of gallstones (Dingil, 1990). Oil derived from its wood is widely used in the perfume industry and medicine (Gultekin, 2004). Its evergreen leaves with long and persistent red berries make it a suitable ornamental plant for landscaping. In recent years, tourist goods have been produced from the green shoots in the Isparta and Antalya provinces of Turkey. These ornaments are exported to several countries. The wood of the plant is also used as firewood in bakeries. A. andrachne is an essential species in afforestation and erosion control studies because it is an arid species with kinky nature and desirable soil demand.

Expected climate change and global warming could lead to changes in species' natural distribution and the effects of harmful factors (Bellard et al., 2012; Arslan, 2019). As a result, global climate change scenarios have gained importance in recent years to understand how the earth will react to climate change in the future (Remya et al., 2015; Moss et al., 2010; Hunt et al., 2007; El-Keblawy, 2014, Zare Chahouki et al., 2012; Zare Chahouki \& Piri Sahragard, 2016).

Analyzing climate change effects on plant species in Turkey has vital importance for planning these species' future use. The potential future distribution of species in different scenarios can be demonstrated by the Maxent (Maximum Entropy Modeling) program using point field records, and layers created using digital bioclimate data.

Maximum entropy models offer a clean approach to joining various logical confirmation pieces, keeping in mind the end goal to gauge the likelihood of a specific phonetic class happening with one particular semantic setting. Maximum entropy is a supervised probabilistic machine learning model used for sequential data classification (Khan, 2016).

The RCPs (Representative Concentration Pathway) is consistent with a wide range of possible future anthropogenic changes, Greenhouse Gas Emissions and aim to represent their atmospheric concentrations (Collins \& Knutti, 2014). RCP 2.6 assumes 
that global annual Greenhouse Gas emissions (measured in CO2-equivalents) peak between 2010-2020, with emissions declining substantially after that. Emissions in RCP 4.5 peak around 2040 and then lower. In RCP 6, emissions peak around 2080, then lower. In RCP 8.5, emissions continue to rise throughout the $21^{\text {st }}$ century (Meinshausen et al., 2011). The IPCC studies the carbon cycle separately, predicting higher ocean uptake of carbon corresponding to higher concentration pathways. Still, land carbon uptake is much more uncertain due to the combined effect of climate change and land-use changes (IPCC, 2014).

In this study, we aim to determine potential distribution areas of $A$. andrachne under various climate change scenarios and estimate how the spread of the species will be affected by climate change. In addition to the current situation, RCP 4.5 and RCP 8.5 climate change scenarios are presented for $A$. andrachne.

\section{Material and Method}

The data about the spatial distribution of Arbutus andrachne are obtained from our observations and previous literature records (OGM 2019; Davis 1965; 1978). Also, data obtained from the WorldClim (URL-1) database for about $1 \mathrm{~km}^{2}$ (30 arc seconds) were used as the bioclim layers' base. Sampling sites and field data on $A$. andrachne are presented in Figure 1 and Table 1. The test data used in modeling are given in Table 2.

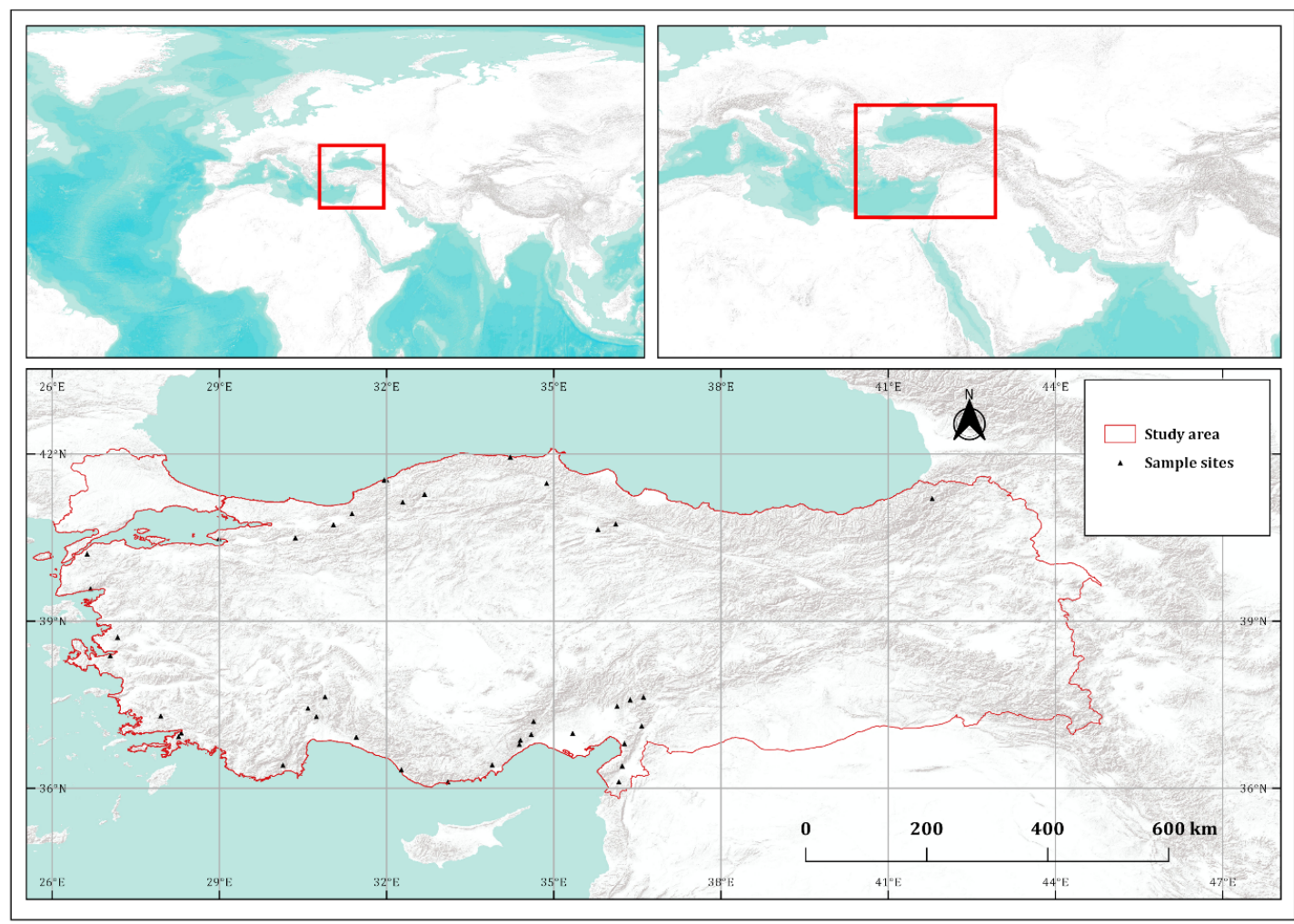

Fig. 1. Examined sample sites for Arbutus andrachne from Turkey as a study area. 
Table 1. Distribution and climatic data of sites used in the present study.

\begin{tabular}{|c|c|c|c|c|c|c|c|}
\hline $\begin{array}{l}\text { Site } \\
\text { code }\end{array}$ & Latitude & Longitude & City & District & $\begin{array}{c}\text { Altitude } \\
\text { (m) }\end{array}$ & $\begin{array}{c}\text { Total annual } \\
\text { Precipitation } \\
(\mathbf{m m})\end{array}$ & $\begin{array}{c}\text { Temperature } \\
\left({ }^{\circ} \mathrm{C}\right)\end{array}$ \\
\hline 1 & $36^{\circ} 59^{\prime} 28^{\prime \prime}$ & $35^{\circ} 20^{\prime} 20^{\prime \prime}$ & Adana & Yüreğir & 28 & 58.25 & 18.98 \\
\hline 2 & $37^{\circ} 28^{\prime} 35^{\prime \prime}$ & $36^{\circ} 8^{\prime} 9^{\prime \prime}$ & Osmaniye & Kadirli & 277 & 65.92 & 17.51 \\
\hline 3 & $40^{\circ} 38^{\prime} 55^{\prime \prime}$ & $35^{\circ} 47^{\prime} 30^{\prime \prime}$ & Amasya & Merkez & 500 & 37.17 & 11.41 \\
\hline 4 & $40^{\circ} 44^{\prime} 44^{\prime \prime}$ & $36^{\circ} 6^{\prime} 41^{\prime \prime}$ & Amasya & Merkez & 321 & 42.08 & 12.39 \\
\hline 5 & $36^{\circ} 20^{\prime} 7^{\prime \prime}$ & $32^{\circ} 16^{\prime} 0^{\prime \prime}$ & Antalya & Alanya & 297 & 70.75 & 17.70 \\
\hline 6 & $36^{\circ} 55^{\prime} 22^{\prime \prime}$ & $31^{\circ} 27^{\prime} 27^{\prime \prime}$ & Antalya & Manavgat & 429 & 74.25 & 16.63 \\
\hline 7 & $41^{\circ} 12^{\prime} 8^{\prime \prime}$ & $41^{\circ} 47^{\prime} 14^{\prime \prime}$ & Artvin & Merkez & 538 & 94.17 & 12.12 \\
\hline 8 & $40^{\circ} 44^{\prime} 3^{\prime \prime}$ & $31^{\circ} 2^{\prime} 51^{\prime \prime}$ & Düzce & Gölyaka & 447 & 58.50 & 11.35 \\
\hline 9 & $40^{\circ} 55^{\prime} 54^{\prime \prime}$ & $31^{\circ} 22^{\prime} 45^{\prime \prime}$ & Düzce & Yığılca & 526 & 58.83 & 11.05 \\
\hline 10 & $40^{\circ} 29^{\prime} 1^{\prime \prime}$ & $28^{\circ} 59^{\prime} 33^{\prime \prime}$ & Yalova & Armutlu & 484 & 54.67 & 12.42 \\
\hline 11 & $37^{\circ} 26^{\prime} 27^{\prime \prime}$ & $30^{\circ} 35^{\prime} 21^{\prime \prime}$ & Burdur & Bucak & 868 & 43.50 & 12.65 \\
\hline 12 & $37^{\circ} 17^{\prime} 25^{\prime \prime}$ & $30^{\circ} 44^{\prime} 30^{\prime \prime}$ & Burdur & Bucak & 601 & 50.67 & 14.78 \\
\hline 13 & $37^{\circ} 38^{\prime} 44^{\prime \prime}$ & $30^{\circ} 53^{\prime} 45^{\prime \prime}$ & Isparta & Eğirdir & 1080 & 46.75 & 11.65 \\
\hline 14 & $38^{\circ} 22^{\prime} 54^{\prime \prime}$ & $27^{\circ} 2^{\prime} 38^{\prime \prime}$ & Izmir & Balçova & 339 & 57.92 & 16.18 \\
\hline 15 & $37^{\circ} 35^{\prime} 27^{\prime \prime}$ & $36^{\circ} 22^{\prime} 8^{\prime \prime}$ & K. Maras & Andırın & 1123 & 58.33 & 11.05 \\
\hline 16 & $36^{\circ} 24^{\prime} 10^{\prime \prime}$ & $36^{\circ} 13^{\prime} 35^{\prime \prime}$ & Hatay & Merkez & 253 & 76.08 & 18.58 \\
\hline 17 & $36^{\circ} 24^{\prime} 10^{\prime \prime}$ & $36^{\circ} 13^{\prime} 35^{\prime \prime}$ & Hatay & Merkez & 253 & 76.08 & 18.58 \\
\hline 18 & $36^{\circ} 7^{\prime} 6^{\prime \prime}$ & $36^{\circ} 9^{\prime} 58^{\prime \prime}$ & Hatay & Merkez & 454 & 80.67 & 16.92 \\
\hline 19 & $36^{\circ} 48^{\prime} 19^{\prime \prime}$ & $36^{\circ} 16^{\prime} 0^{\prime \prime}$ & Hatay & Dörtyo & 433 & 74.00 & 16.09 \\
\hline 20 & $37^{\circ} 38^{\prime} 21^{\prime \prime}$ & $36^{\circ} 36^{\prime} 31^{\prime \prime}$ & K. Maras & Merkez & 511 & 58.83 & 15.00 \\
\hline 21 & $41^{\circ} 56^{\prime} 51^{\prime \prime}$ & $34^{\circ} 13^{\prime} 11^{\prime \prime}$ & Kastamonu & Çatalzeytin & 254 & 77.00 & 12.85 \\
\hline 22 & $36^{\circ} 47^{\prime} 33^{\prime \prime}$ & $34^{\circ} 22^{\prime} 54^{\prime \prime}$ & Mersin & Merkez & 395 & 59.58 & 16.43 \\
\hline 23 & $36^{\circ} 58^{\prime} 8^{\prime \prime}$ & $34^{\circ} 35^{\prime} 44^{\prime \prime}$ & Mersin & Merkez & 404 & 61.42 & 16.26 \\
\hline 24 & $37^{\circ} 12^{\prime} 9^{\prime \prime}$ & $34^{\circ} 38^{\prime} 13^{\prime \prime}$ & Mersin & Tarsus & 794 & 56.25 & 13.24 \\
\hline 25 & $36^{\circ} 55^{\prime} 52^{\prime \prime}$ & $28^{\circ} 16^{\prime} 12^{\prime \prime}$ & Mugla & Marmaris & 199 & 84.42 & 17.62 \\
\hline 26 & $40^{\circ} 29^{\prime} 54^{\prime \prime}$ & $30^{\circ} 21^{\prime} 55^{\prime \prime}$ & Sakarya & Geyve & 181 & 53.33 & 12.74 \\
\hline 27 & $41^{\circ} 16^{\prime} 49^{\prime \prime}$ & $32^{\circ} 40^{\prime} 58^{\prime \prime}$ & Karabük & Safranbolu & 584 & 56.42 & 10.89 \\
\hline 28 & $41^{\circ} 8^{\prime} 18^{\prime \prime}$ & $32^{\circ} 17^{\prime} 28^{\prime \prime}$ & Karabük & Yenice & 296 & 56.50 & 11.78 \\
\hline
\end{tabular}


Table 2. Attribute information for data tested in the modeling.

\begin{tabular}{|c|c|c|c|c|c|c|c|}
\hline $\begin{array}{l}\text { Site } \\
\text { code }\end{array}$ & Latitude & Longitude & City & District & $\begin{array}{c}\text { Altitude } \\
\text { (m) }\end{array}$ & $\begin{array}{l}\text { Total annual } \\
\text { Precipitation } \\
(\mathbf{m m})\end{array}$ & $\begin{array}{c}\text { Temperature } \\
\left({ }^{\circ} \mathrm{C}\right)\end{array}$ \\
\hline 1 & $36^{\circ} 6^{\prime} 57^{\prime \prime}$ & $33^{\circ} 6^{\prime} 2^{\prime \prime}$ & Mersin & Bozyazı & 16 & 53.17 & 18.58 \\
\hline 2 & $36^{\circ} 52^{\prime} 4^{\prime \prime}$ & $34^{\circ} 23^{\prime} 60^{\prime \prime}$ & Mersin & Merkez & 817 & 57.92 & 14.05 \\
\hline 3 & $37^{\circ} 7^{\prime} 21^{\prime \prime}$ & $36^{\circ} 34^{\prime} 34^{\prime \prime}$ & Gaziantep & Islahiye & 944 & 63.25 & 12.96 \\
\hline 4 & $36^{\circ} 25^{\prime} 19^{\prime \prime}$ & $33^{\circ} 53^{\prime} 40^{\prime \prime}$ & Mersin & Silifke & 180 & 54.50 & 17.98 \\
\hline 5 & $36^{\circ} 25^{\prime} 10^{\prime \prime}$ & $30^{\circ} 8^{\prime} 26^{\prime \prime}$ & Antalya & Finike & 256 & 65.42 & 17.39 \\
\hline 6 & $37^{\circ} 18^{\prime} 7^{\prime \prime}$ & $27^{\circ} 56^{\prime} 55^{\prime \prime}$ & Muğla & Yatağan & 691 & 70.83 & 14.78 \\
\hline 7 & $36^{\circ} 59^{\prime} 50^{\prime \prime}$ & $28^{\circ} 19^{\prime} 5^{\prime \prime}$ & Muğla & Ula & 94 & 87.25 & 18.13 \\
\hline 8 & $38^{\circ} 42^{\prime} 49^{\prime \prime}$ & $27^{\circ} 10^{\prime} 34^{\prime \prime}$ & Izmir & Menemen & 381 & 60.00 & 14.82 \\
\hline 9 & $40^{\circ} 12^{\prime} 31^{\prime \prime}$ & $26^{\circ} 37^{\prime} 46^{\prime \prime}$ & Çanakkale & Lapseki & 183 & 54.75 & 14.08 \\
\hline 10 & $39^{\circ} 35^{\prime} 6^{\prime \prime}$ & $26^{\circ} 41^{\prime} 24^{\prime \prime}$ & Balikesir & Edremit & 150 & 57.17 & 14.25 \\
\hline 11 & $41^{\circ} 28^{\prime} 29^{\prime \prime}$ & $34^{\circ} 52^{\prime} 18^{\prime \prime}$ & Sinop & Boyabat & 380 & 52.25 & 11.88 \\
\hline 12 & $41^{\circ} 32^{\prime} 23^{\prime \prime}$ & $31^{\circ} 59^{\prime} 57^{\prime \prime}$ & Zonguldak & Çaycuma & 160 & 85.83 & 13.23 \\
\hline
\end{tabular}

Various types of Species Distribution Models (SDM) such as CLIMEX, Doup, Genetic Algorithm (GARP), and Maximum Entropy (Maxent) are used to evaluate ecological requirements, ecological responses, and spreading areas (Elith \& Leathwick 2009; Brito et.al., 2009; Wei et.al., 2018). These modeling approaches include using both asset data and continuous and categorical data as input variables, testing for accuracy of estimation, always stable and reliable, even with missing data, small sample sizes, and gaps. Maxent stands out due to its advantages, such as producing a spatially open habitat conformity map directly and evaluating the significance levels of individual environmental variables using the built-in jackknife test (Tsoar et.al., 2007; Phillips \& Dudik 2008; Pearson et.al., 2007). 
Table 3. Climatic variables (www.wordclim.org)

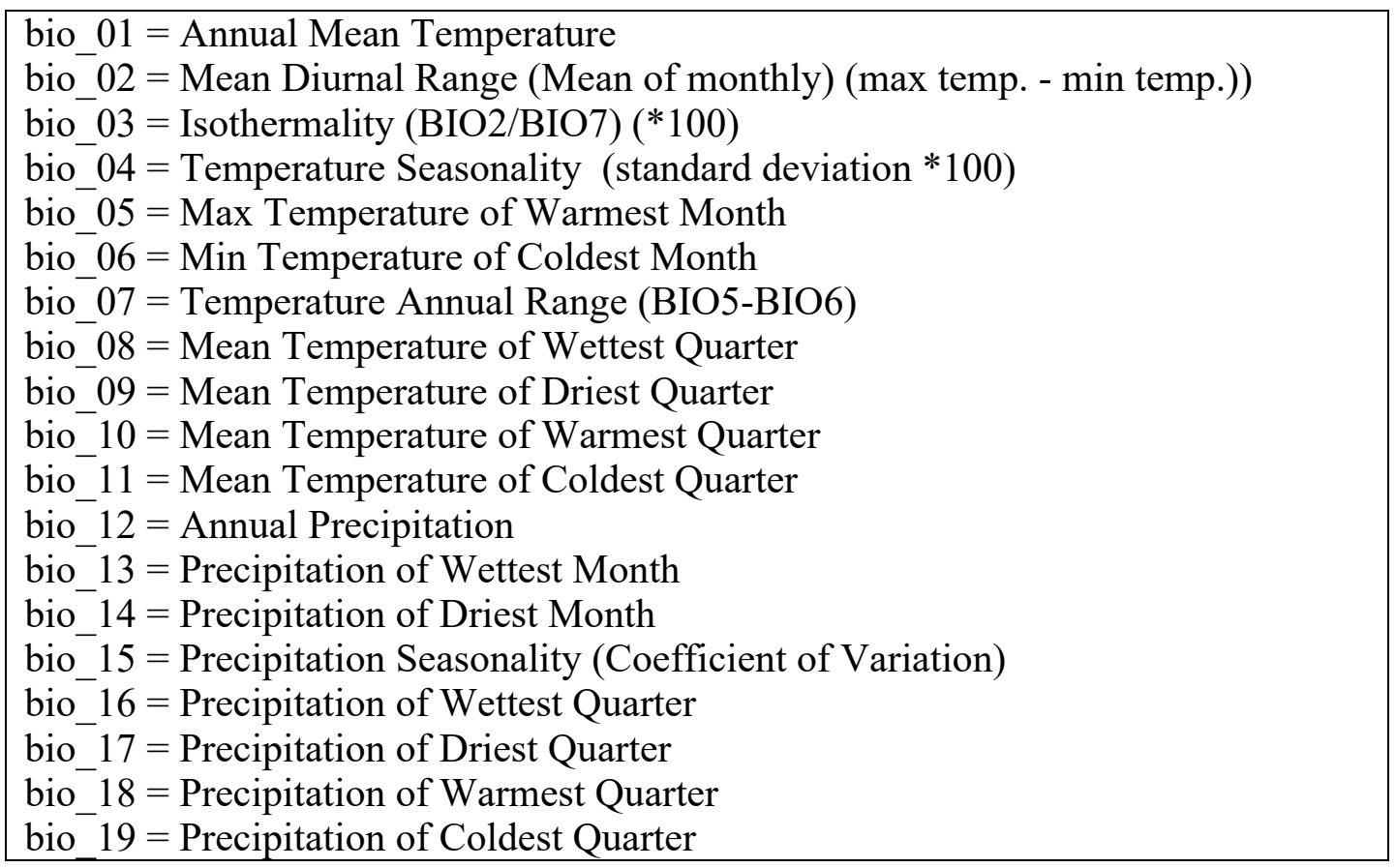

Climate data were composed of parameters from 1950-1990, and 19 climatic variables were used (Hijmans et.al., 2005) (Table 3). The Maximum Entropy algorithm processed these data, and the potential distribution area of the species was determined for nowadays conditions. Also, the possible distribution range of the species between 2050 and 2070 years was modeled according to the climate change scenario of the Hadley Global Environment Model 2 - Earth System (HadGEM2-ES).

The AUC (Area Under the Curve) value was used to determine the Maxent modeling performance. AUC is a value between 0 and 1 , and if this value is more significant than 0.5 , the modeling performs better than a random estimate (Suel, 2014; Mert \& Kirac, 2017; Oruc et.al., 2017; Dulgeroglu \& Aksoy, 2018). To show how the estimation is based on a particular variable, response curves were created. MESS (multivariate environmental similarity surface) analysis was performed to show the location of the new bioclimatic conditions encountered during the process. The jackknife test was applied to determine the contribution of environmental variables used in modeling. 


\section{Results and Discussion}

The potential distribution modeling of Arbutus andrachne in current climatic conditions was better than a random estimate (Figure 2). Figure 3 shows the neglect rate and the projected area as a function of the cumulative threshold. The neglect rate is calculated both in educational records and in test records (if test data are used). The neglect rate should be close to the projected omissions due to the definition of the cumulative threshold. AUC was calculated as 0.919 for training data and 0.871 for test data (Figure 4).

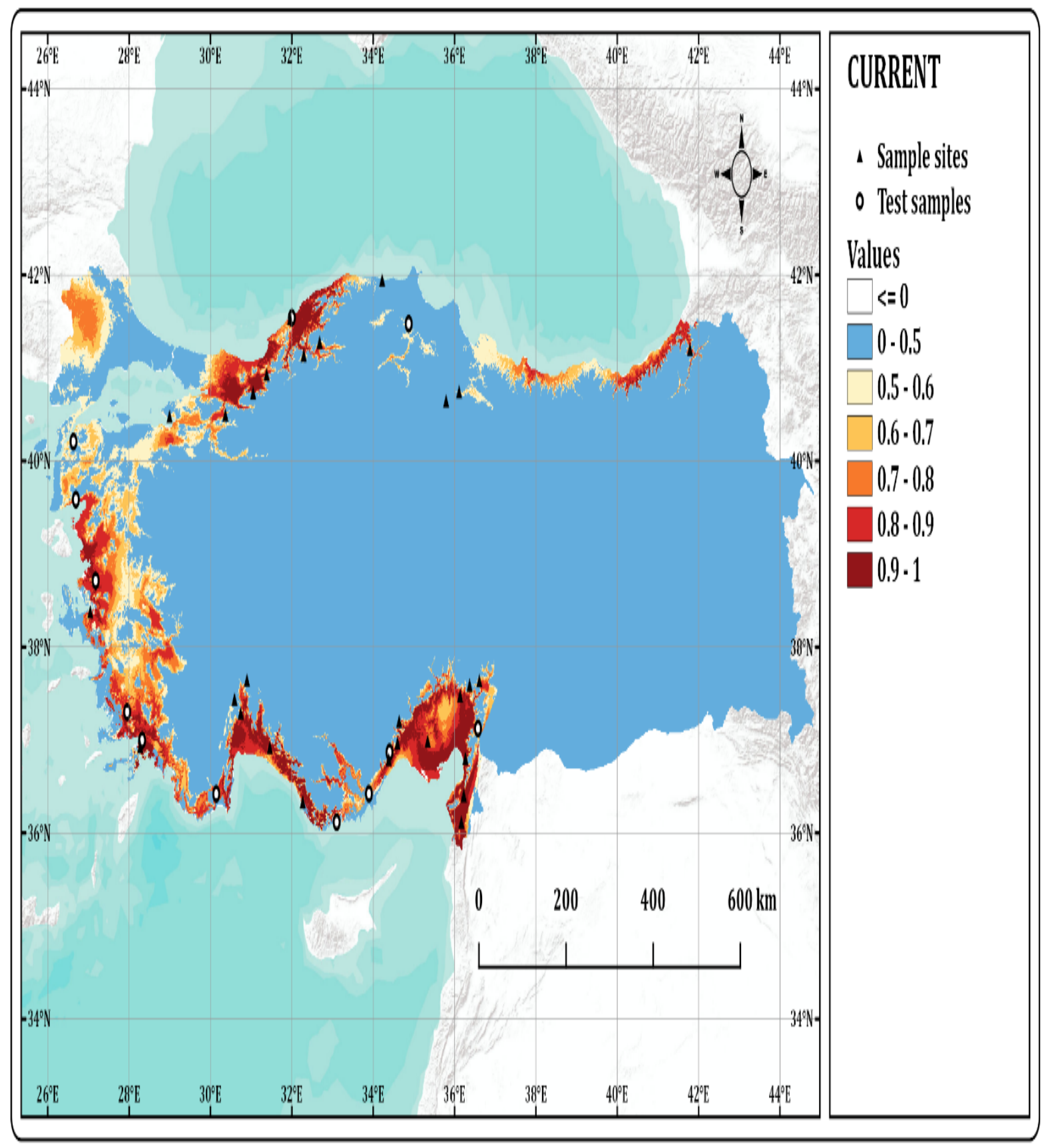

Fig. 2. The potential current distribution of Arbutus andrachne. 
The current distribution map is a representation of the Maxent model for $A$. andrachne. As the values approach 1 , the warm colors indicate areas with betterprescribed conditions. Black triangles show the position of the assets used for training, and circles show the test positions. The established ecological niche model shows the areas where the species exist and areas with no suitable species but with climatic conditions ideal for survival (Pearson, 2007).

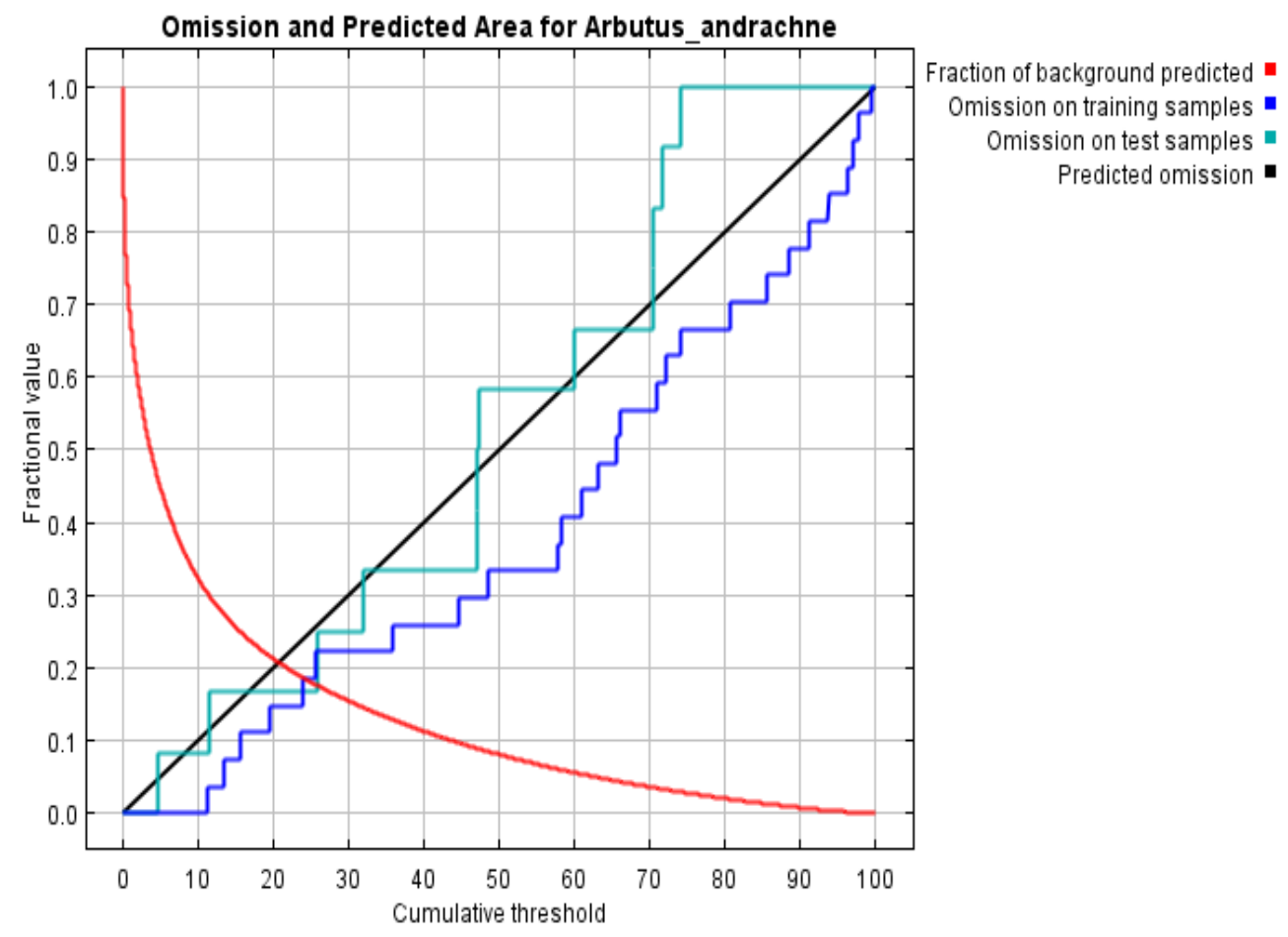

Fig. 3. The neglect rate and the projected area as a function of the cumulative threshold.

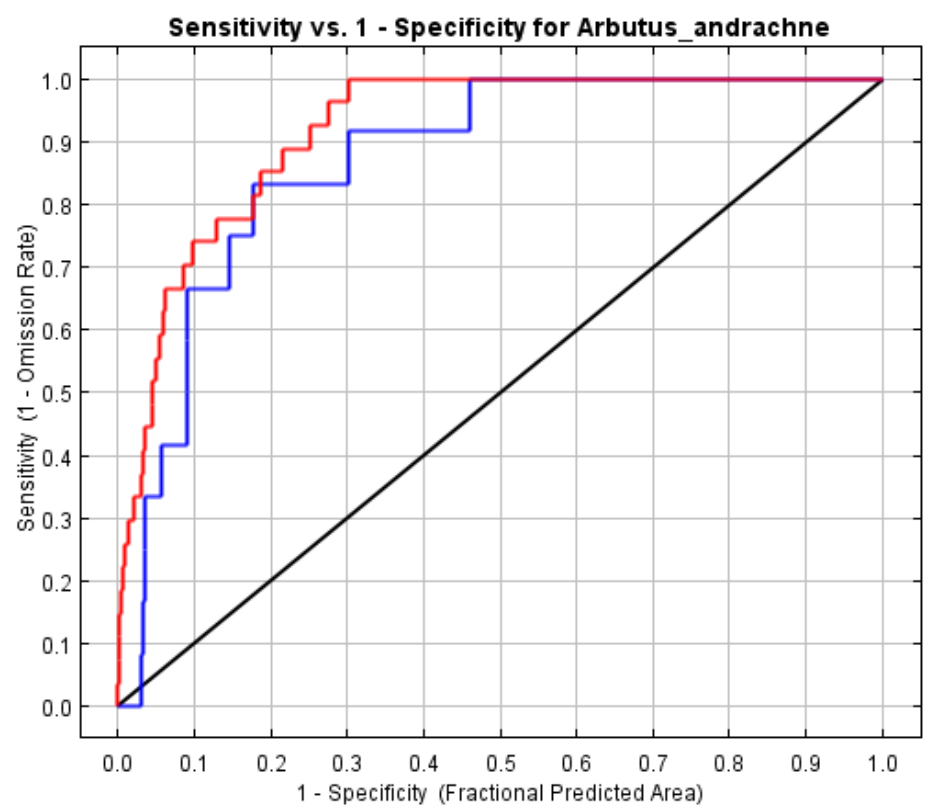

Fig. 4. AUC (Area Under the Curve) and Test data rates. 


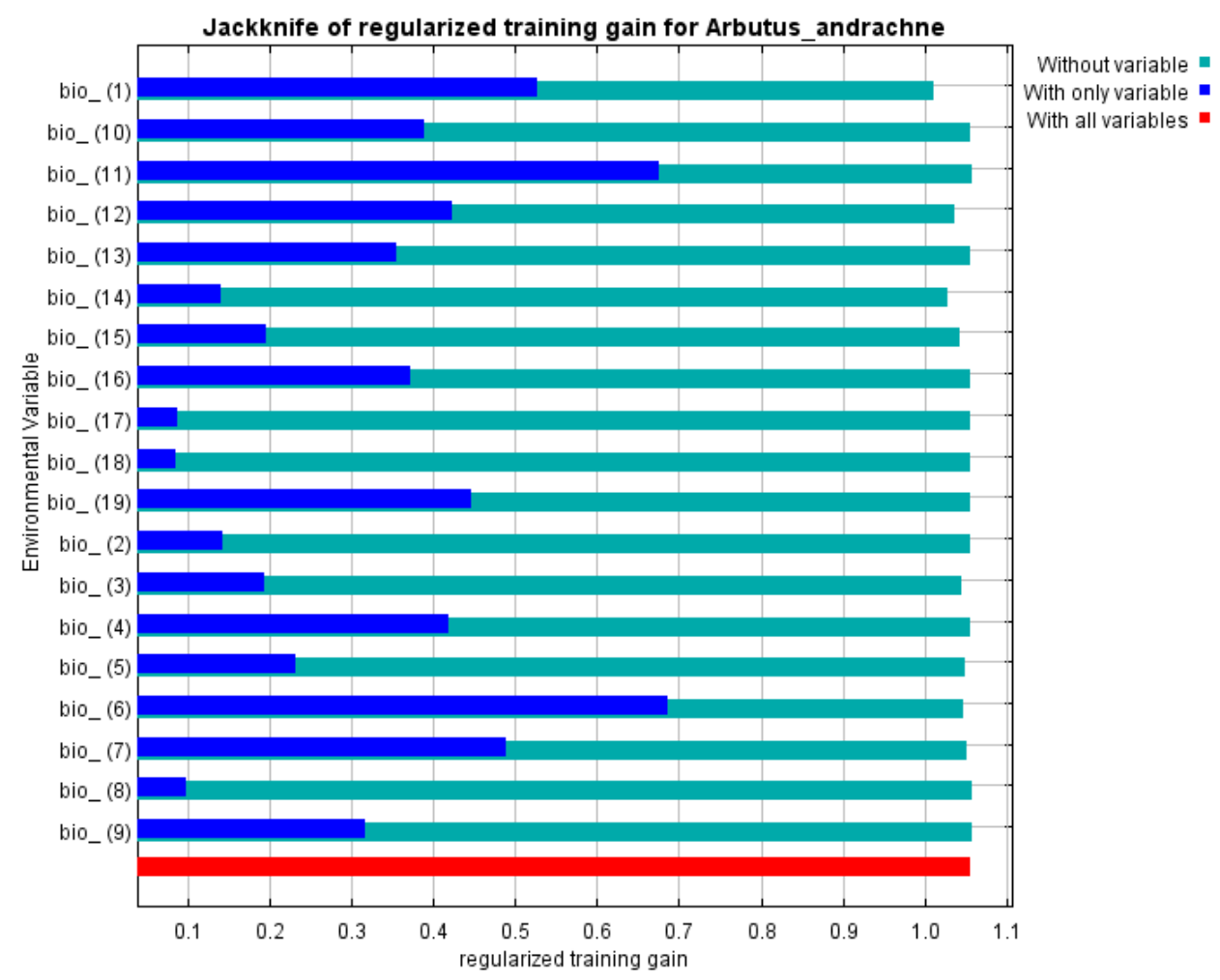

Fig. 5. According to Jackknife test results, environmental variables' relative importance values determine Arbutus andrachne's distribution.

According to the jackknife test results, the environmental variable with the highest gain is the Minimum Temperature of Coldest Month (bio_6). Therefore, it seems to have the most useful information on its own. The environmental variable that reduces the gain most when ignored is Annual Mean Temperature (bio_1), so it seems to have the most information not available in other variables (Figure 5).

The possible distribution models of Arbutus andrachne in 2050 and 2070 were better than a random estimate. The potential distributions of $A$. andrachne under RCP 4.5 and RCP 8.5 climate change scenarios for 2050 and 2070 are given in more detail in Figures 5 and 6. The potential distribution of $A$. andrachne under bioclimatic conditions in 2050 and 2070 decreases in RCP 4.5 and RCP 8.5 scenarios. According to the model results, climate change allows the species to extend its distribution area to the west and north while narrowing its distribution area in the southern regions (Figure 6 and Figure 7). In the current habitat, the current climatic conditions are not considered very suitable, especially in the south of the country to live in 2070.

On the other hand, the spread in Marmara and Western Black Sea regions is increasing. As a result, these estimates show that the geographical distribution of A. andrachne will be reduced in the future. That habitat will lead to significant loss according to the climate change scenario. 


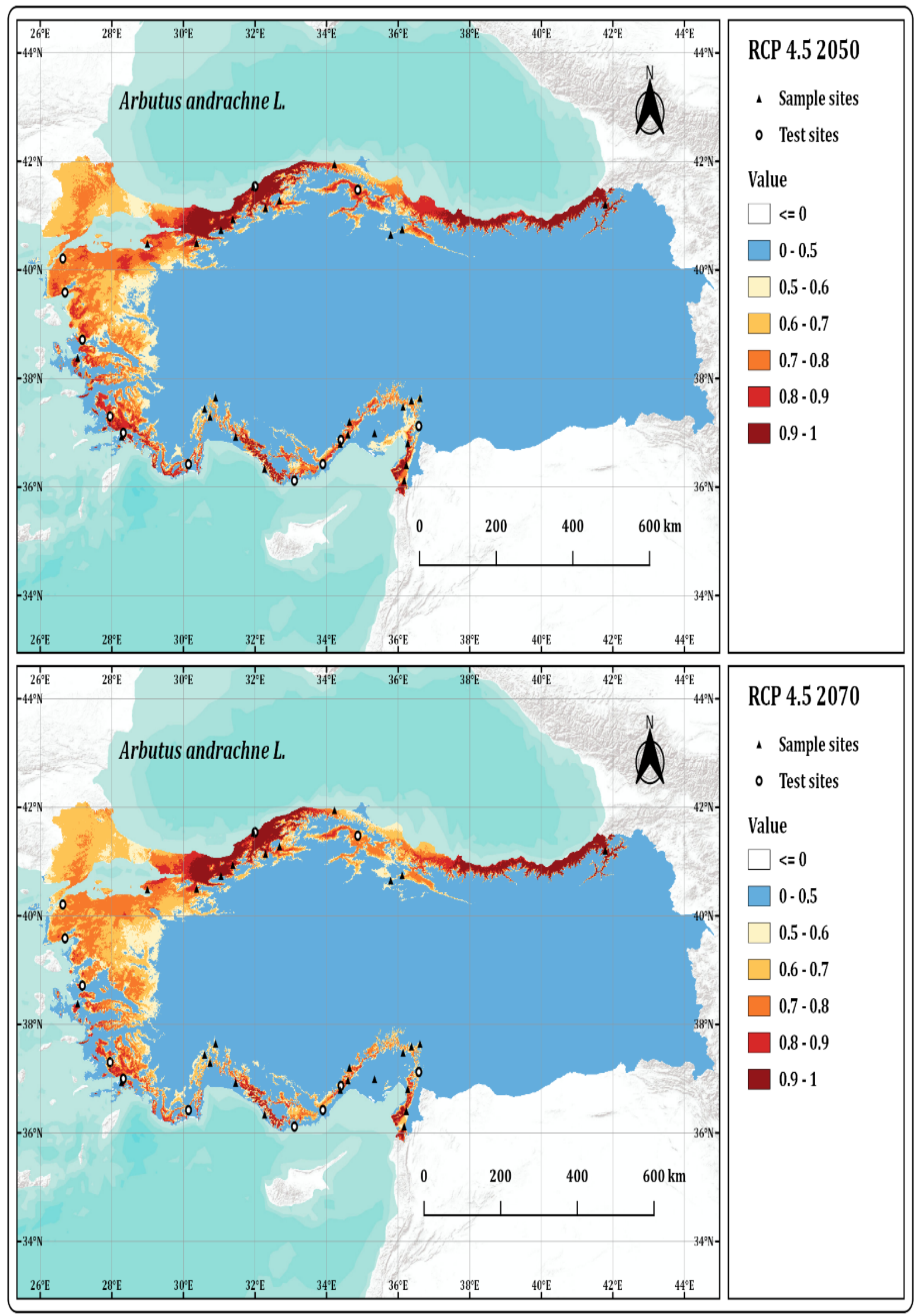

Fig. 6. Future potential distribution of Arbutus andrachne L. in Turkey according to RCP4.5. 


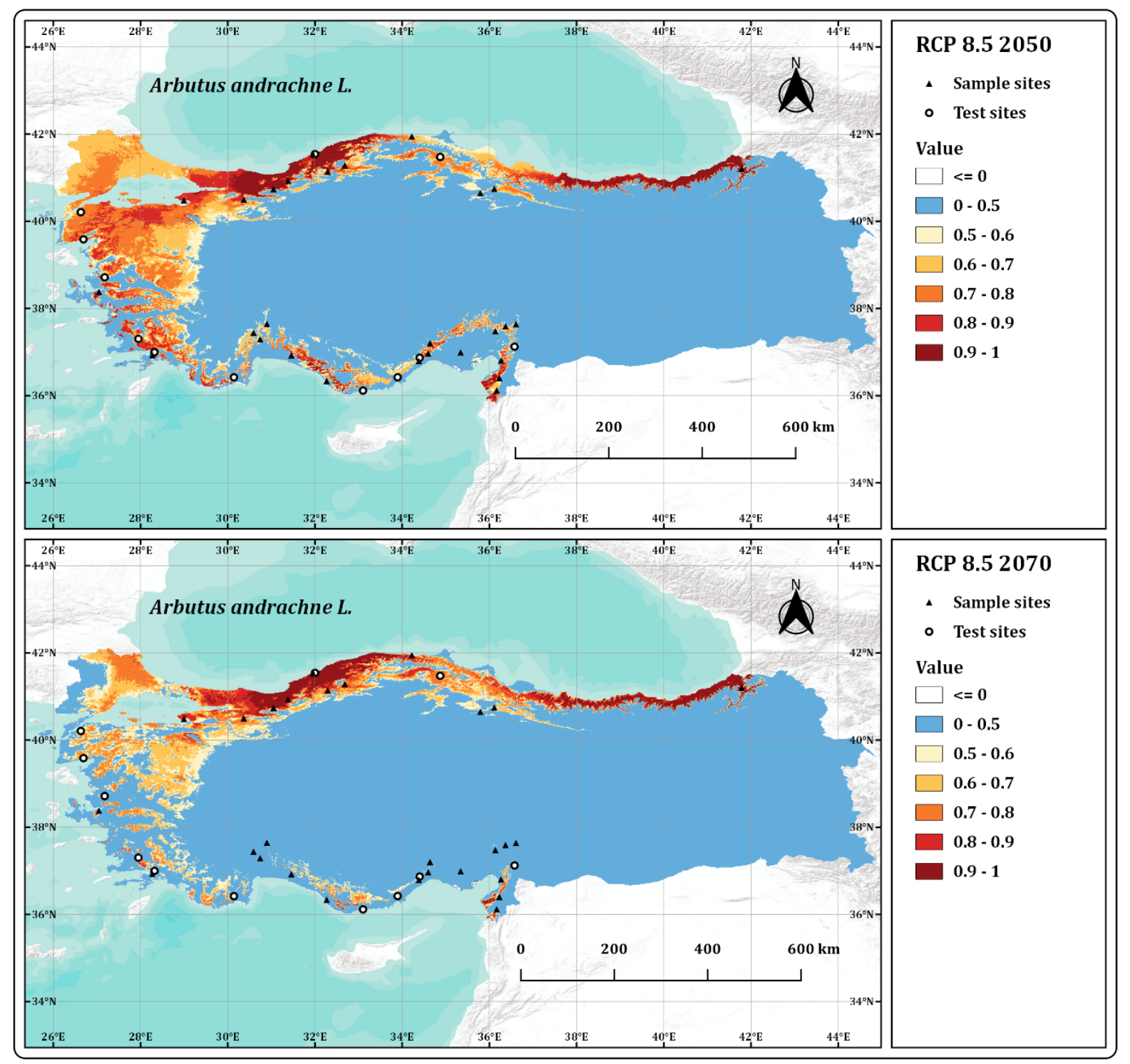

Fig. 7. Future potential distribution of Arbutus andrachne L. in Turkey according to RCP8.5.

Many studies on climate change state that plant distribution will change (Akyol \& Orucu, 2019; Arslan \& Orucu, 2019; Sarikaya \& Orucu, 2019). It has been reported that endemic species in the Mediterranean will be less affected by natural and anthropogenic factors because they are stress-tolerant and adapted to challenging habitats (Medail \& Verlaque, 1997; Dulgeroglu \& Aksoy, 2018).

In studies conducted on the effects of climate changes on plants, it is foreseen that the spread of some species will decrease. It has been reported that there are hazards of extinction, especially if plants spreading in the Mediterranean basin do not adapt to climate change (Moiseev \& Shiyatov, 2003; IPCC, 2014; Khanum et al., 2013; Dülgeroğlu \& Aksoy, 2018; Orucu \& Akyol, 2019).Piri Sahragard et.al. (2018) stated that potential distribution maps of plant habitats prepared using Maxent modeling are of higher priority for conservation on the local scale in arid mountainous rangelands.

The study by Riberio et al. (2017) used the Maxent program on Arbutus unedo in Portugal. It indicated that species distribution would change towards the country's central and northern regions according to projections for 2050 and 2070. Our study supports this research. 


\section{Conclusions}

Our study determined that Arbutus andrachne's distribution will increase in western and northern parts of Turkey according to 2050 and 2070 scenarios. However, possible habitat loss can reach serious rates. The emergence of invasive species due to harsh habitat conditions and climate changes indicates that suitable conservation measures should be taken, especially for species with limited spread.In this context, because $A$. andrachne is an intensive species in terms of land demand, it is of great importance to take into account potential expansion in the future and to take necessary measures for use in afforestation and erosion control works and the utilization of non-wood forest products. Climate change is not limited to habitat loss, and the ecosystem and ecology of the species will change. Therefore, more detailed and comprehensive studies on the interaction of climate change and Arbutus species are required.

\section{References}

Akyol, A. \& Orucu, O.K. (2019) Investigation and evaluation of stone pine (Pinus pinea L.) current and future potential distribution under climate change in Turkey. Cerne 25: 415-423.

Anşin, R. \& Özkan, Z.C. (1993) Seed Plants (Spermatophyta), Karadeniz Technical University, Trabzon, Pp. 517.

Arslan, E.S. (2019) Evaluation of urban road trees in terms of ecosystem services according to climate change scenarios and species distribution model: The case of Robinia pseudoacacia L. Turkish Journal of Forestry, 20(2): 142-148.

Arslan, E.S. \& Orucu, O.K. (2019) Present and future potential distribution of the Pinus nigra Arnold. Moreover, Pinus sylvestris L. using Maxent Model. Int. J. Ecosyst. Ecol. Sci. 9: 787-798.

Aslan, V. (2011) Investigations on Some Morphological Features of Arbutus andrachne L. Growing in Çandır (SutculerIsparta) Province. Master Thesis, Suleyman Demirel University, Pp.47.

Bektas, I. (2014) Introduction of 3rd International Non-wood Forest Products Symposium Proceedings. Kahramanmaras, Turkey. vi

Bellard, C., Bertelsmeier, C., Leadley, P., Thuiller, W. \& Courchamp, F. (2012) Impacts of climate change on the future of biodiversity, Ecology letters, 15: 77-365.

Brito, J.C., André, L.A., Álvares, F. \& Fabrice, C. (2009) Biogeography and conservation of taxa from remote regions: An application of ecological-niche based models and GIS to North-African Canids. Biological Conservation, 142(12): 30203029.

Collins, M., Knutti, R. (2014) The New Concentration Driven RCP Scenarios, and their Extensions, In Long-term Climate Change: Projections, Commitments, and Irreversibility, Chapter:12, pp. 10451047.

Davis, P.H. (1965) The Flora of Turkey and East Aegean Islands, Vol.9. Edinburgh University Press, Edinburgh. Pp.724.

Davis, P.H. (1978) Flora of Turkey and East Aegean Islands, Vol.6. Edinburgh University Press, Edinburgh. Pp.825.

Dingil, S. (1990) Anatolia with plants. Plants and Flowers Part of Historical Touristic Regions in South, Central, and Western Anatolia. Guide, Antalya.Pp 142

Dulgeroglu, C. \& Aksoy, A. (2018) Predicting Impacts of Climate Change on Geographic Distribution of Origanum minutiflorum Schwarz \& P. H. Davis Using Maximum Entropy Algorithm. Erzincan University Journal of Science and Technology, 11(2): 182-190.

Elith, J. \& Leathwick, J.R. (2009) Species distribution models: ecological explanation and prediction across space 
and time, Annual Review Of Ecology, Evolution, Systematics, 40: 677-97.

El-Keblawy, A. (2014) Impact of climate change on biodiversity loss and extinction of endemic plants of arid land mountains. $\mathbf{J}$ Biodivers Endanger Species, 2(120), 2.

Gezgin, D. (2006) Plant myths. Sel Publications, Istanbul. Pp. 144.

Gultekin, H.C. (2004) Some Determinations About Sapling Production Studies on Sandal (Arbutus andrachne L.) and (Arbutus unedo L.). Forest Engineering Journal, 10-11-12: 10-11.

Gungor, I., Atatoprak, A., Ozer, F., Akdag, N. \& Kandemir, N.I. (2002) World of Plants, Principles of Sapling Growing, Lazer Publications, Ankara. Pp. 384.

Hijmans, R.J., Cameron, S.E., Parra, J.L., Jones P.G. \& Jarvis, A. (2005) Very high resolution interpolated climate surfaces for global land areas. International Journal of Climatology, 25: 1965-1978.

Hunt, L.P.; Petty, S.; Cowley, R.; Fisher, A.; Ash, A.J. \& MacDonald, N. (2007) Factors affecting the management of cattle grazing distribution in northern Australia: preliminary observations on the effect of paddock size and water points. The Rangeland Journal, 29: 79-169.

IPCC (2014) IPCC AR5- Technical Summary- TFE.7 Carbon Cycle Perturbation and Uncertainties, Pp. 33-115.

Kayacik, H. (1982) Special Systematic of Forest and Park Trees. Istanbul University, Istanbul, Pp.833.

Khan, W.; Daud, A.; Nasir, J.A. \& Amjad, T. (2016) A survey on the stateof-the-art machine learning models in the context of NLP. Kuwait Journal of Science, 43(4): 95-113.

Khanum R., Mumtaz A.S. \& Kumar S. (2013) Predicting impacts of climate change on medicinal asclepiads of Pakistan using Maxent modeling. Acta Oecologica-
International Journal of Ecology, 49: 2331.

Medail, F. \& Verlaque, R. (1997) Ecological characteristics and rarity of endemic plants from southeast France and Corsica: Implications for biodiversity conservation. Biological Conservation, 80(3): 269-281.

Meinshausen, M; Smith, S. J; Calvin, K; Daniel, J. S; Kainuma, M. L. T. et al. (2011) The RCP greenhouse gas concentrations and their extensions from 1765 to 2300 . Climatic Change, 109 (1-2): 213-241.

Mert, A. \& Kirac, A. (2017) Habitat Suitability Mapping of Anatololacerta danfordi (Günter, 1876) in Isparta-Sütçüler District. Bilge International Journal of Science and Technology Research, 1(1): 16-22.

Moiseev, P.A. \& Shiyatov, S.G. (2003) The use of old landscape photographs for studying vegetation dynamics at the tree line ecotone in the Ural Highlands, Russia. In: Nagy, L. (Ed.), Alpine Biodiversity in Europe. Springer-Verlag, Berlin. 423-436

Moss, R.H; Edmonds, J.A; Hibbard, K.A; Manning, M.R; Rose, S.K. et al. (2010) The next generation of scenarios for climate change research and assessment. Nature, 463: 747.

Nuh, D. (2015) A research on seedling propagation of madrone (Arbutus andrachne L.). Master Thesis, Artvin Coruh University, Pp.46.

OGM. (2019) Biological Diversity and Non-Wood Forest Products Database (BIYOD). Pp 48

Onursal, C.E., Gozlekci, S. (2007) The Effects of Some Pre-Sowing Treatments on Seed Germination Percentage and Duration of Sandal Wood (Arbutus andrachne L.) Trees. Akdeniz University Journal of the Faculty of Agriculture, 20 (2): 211-218. 
Oruc, M.S.; Mert, A. \& Ozdemir, I. (2017) Modeling Habitat Suitability for Red Deer (Cervus elaphus L.) Using Environmental Variables in Çatacık Region, Eskișehir. Bilge International Journal of Science and Technology Research, 1(2): 135-142.

Orucu, O.K.; Akyol, A. (2019). Investigations of Effects of Climate Change on Potential Distribution of Myrtus communis subsp. Communis in Turkey by Maxent. In: Bozdogan, M., Bozdogan, N.Y. (Ed.), New horizons in Agriculture, Forestry and Aquaculture, Pp.30-49.

Ozkan, Z. C. \& Akbulut, S. (2014) Forest Botany Lecture Notes, Trabzon. Pp. 16.

Pearson, R.G. (2007) Species Distribution Modeling for Conservation Educators and Practitioners. Synthesis. American Museum of Natural History Lessons in Conservation, 3:54-89.

Pearson, R.G.; Raxworthy, C.J.; Nakamura, M. \& Peterson, A.T. (2007) Predicting species distributions from small numbers of occurrence records: a test case using cryptic geckos in Madagascar, Journal of Biogeography, 34: 17-102.

Phillips, S.J. \& Dudik, M. (2008) Modeling species distributions with Maxent: new extensions and a comprehensive evaluation, Ecography, 31: 75-161.

Piri Sahragard, H.; Ajorlo, M. \& Karami, P. (2018) Modeling habitat suitability of range plant species using random forest method in arid mountainous rangelands, Journal of Mountain Science, 15: 2159-2171.

Remya, K.; Ramachandran, A. \& Jayakumar, S. (2015) Predicting the current and future suitable habitat distribution of Myristica dactyloides Gaertn. We are using the MaxEnt model in the Eastern Ghats, India, Ecological Engineering, 82: 88-184.
Sarikaya, A.G. \& Orucu, O.K. (2019) Prediction of potential and future distribution areas of Anatolian Chesnut (Castanea sativa Mill.) by using maximum entropy (Maxent) modeling depending on climate change in Turkey. International Journal of Ecosystems and Ecology Science, 9(4): 699-708.

Suel, H. (2014) Mapping habitat suitability of game animals in Sütçüler district, Isparta. Ph.D. Thesis, Suleyman Demirel University, Isparta. Pp 151

Sumbul, H; Oz, M; Erdogan, A; Gokoglu, M; Gokturk, R.S. et al. (2005) Nature Guide Turkey, Mart Publication, Istanbul, Pp. 797.

Tsoar, A.; Allouche, O.; Steinitz, O.; Rotem, D.; Kadmon, R. (2007) A comparative evaluation of presence-only methods for modeling species distribution. Biodiversity Research, 13: 397-405.

URL-1. www.worldclim.org. 03.03.2019

Wei, B.; Wang, R.; Hou, K.; Wang, X. \& Wu, W. (2018) Predicting the current and future cultivation regions of Carthamus tinctorius L. Using MaxEnt model under climate change in China, Global Ecology and Conservation, 16: 112

Zare Chahouki, M.A.; Khalasi Ahvazi, L. \& Azarnivand, H. (2012) Comparison of three modeling approaches for predicting plant species distribution in mountainous scrub vegetation (Semnan rangelands, Iran), Polish Journal of Ecology, 60: 105-117.

Zare Chahouki, M.A. \& Piri Sahragard, H. (2016) MaxEnt modeling for distribution of plant species habitats of rangelands (Iran), Polish Journal of Ecology, 64: 453-467. 


$\begin{array}{ll}\text { Submitted } & : 17 / 05 / 2019 \\ \text { Revised } & : 19 / 03 / 2020 \\ \text { Accepted } & : 8 / 04 / 2020 \\ \text { DOI } & : 10.48129 / \text { kjs.v48i2.7882 }\end{array}$

